九州大学学術情報リポジトリ

Kyushu University Institutional Repository

Trial for Rapid Identification of Pathogens from Blasted Pear Blossoms and Rotted Radish Leaves by the Direct Colony TLC and Whole Cellular Fatty Acid Analysis

Khan, Abu Ashraf

Laboratory of Plant Pathology, Faculty of Agriculture, Kyushu University

Furuya, Naruto

Laboratory of Plant Pathology, Faculty of Agriculture, Kyushu University

Matsumoto, Masaru

Institute of Tropical Agriculture, Kyushu University

Matsuyama, Nobuaki

Laboratory of Plant Pathology, Faculty of Agriculture, Kyushu University

https://doi.org/10.5109/24277

出版情報：九州大学大学院農学研究院紀要. 43 (3/4)，pp.327-335，1999-02. Kyushu University バージョン：

権利関係 : 
J. Fac. Agr., Kyushu Univ., 43 (3-4), 327-335 (1999)

\title{
Trial for Rapid Identification of Pathogens from Blasted Pear Blossoms and Rotted Radish Leaves by the Direct Colony TLC and Whole Cellular Fatty Acid Analysis
}

\author{
Abu Ashraf Khan, Naruto Furuya, Masaru Matsumoto* and \\ Nobuaki Matsuyama \\ Laboratory of Plant Pathology, Faculty of Agriculture, \\ Kyushu University, Fukuoka 812-8581, Japan \\ (Received October 23, 1998 and accepted November 6, 1998)
}

\begin{abstract}
Rapid identification of phytopathogenic bacteria isolated from blasted pear blossoms and rotted radish leaves was tricd by the direct colony TLC and whole cellular fatty acid analysis. All the 22 reference strains of fluorescent pseudomonads exhibited similar chromatograms with those of the pear and radish strains at the direct colony TLC. A dendrogram of strains based on fatty acid compositions showed that all pathovars of $P$. syringae, $P$. viridifiava and the peiar and radish strains were closely related with lauric acid and palmitoleic acid as their major fatty acids. On the other hand, $P$. marginalis, $P$. fuorescens and $P$. aeruginosa predominantly containing an widentified fatty acid, were clustered separately. The results of the direct colony TLC and fatty acid arlalysis suggested that the pear and radish strains belonged to $P$. syringae or $P$. viridiflava. Physiological and biochemical tests of the pear and radish strains confirmed that pear and radish strains were $P$. syringae and $P$. viridiflava, respectively. The direct. colony TLC and/or whole cellular fatly acid analysis in combination with some selected physiological and biochemical tests will be convenient and practical approach for rapid identification of phytopathogenic bacteria.
\end{abstract}

\section{INTRODUCTION}

Bacterial pathogens are generally identified by physiological and biochemical tests. But all these tests are laborious and time-consuming. Therefore, development of rapid identification methods for phytopathogenic bacteria has been emphasized. Fatty acid analysis of bacterial cells is important tool for classification and identification of bacteria (De Boer and Sasser, 1986; Kori et al., 1992; Roy, 1988; Stead, 1992). The fatty acid data are more useful for identification of bacteria when they are used in combination with selected conventional tests (Wallace et al., 1988).

The direct colony thin layer chromatography (TLC) for rapid detection and identification of bacterial lipids was invented by Matsuyama et al., (1986) and applied successfully for rapid differentiation of phytopathogenic bacteria (Matsuyama et al., 1993a,b,c; Matsuyama and Furuya, 1993d; Matsuyama, 1995a,b). Practical use of this method for identification of phytopathogenic bacteria from diseased plants is in progress.

In this report, we describe the results of practical application of the direct colony TLC and whole cellular fatty acid analysis by GLC for identification of two bacterial strains, which were isolated from blasted pear (Pyrus serolina) blossoms and rotted radish

\footnotetext{
* Institute of Tropical Agriculture, Kyushu University, Fukuoka 812-8581, Japan
} 
(Raphanus sativus) leaves. Simultaneously, the conventional physiological and biochemical tests were also conducted for confirmation of the results of TLC and GLC methods.

\section{MATERIALS AND METHODS}

\section{Bacterial strains}

Two strains were isolated from blasted pear blossoms and rotted radish leaves at Fukuoka Prefecture and used in this study. Other strains of fluorescent pseudomonads used as reference strains are listed in Table 1.

Tubble 1. List of fluorescent pseudornonads used as reference.

\begin{tabular}{|c|c|c|}
\hline Bacterial species & Isolate & Source \\
\hline \multicolumn{3}{|l|}{ Pseudomonas syringae } \\
\hline pv. syringae & ATCC $19310^{\mathrm{T}}$ & ATCC \\
\hline pv. oryzae & MAFF 301538 & NIAR \\
\hline pv. tabaci & $\mathrm{PA}-28$ & KTES \\
\hline pv. tabaci & $\mathrm{Ku}-7102$ & $\mathrm{AKIJ}$ \\
\hline pv. lachrymans & 1319 & NLAS \\
\hline pv. lachrymans & 1321 & $"$ \\
\hline pv. mori & $\mathrm{P}-23$ & $"$ \\
\hline pv. pisi & MAFF 301211 & NIAR \\
\hline pv. pisi & MAFF 301213 & $"$ \\
\hline pv theae & MAF' 750001 & $"$ \\
\hline pv. coronafaciens & MAFF 301314 & $"$ \\
\hline pv. phaseolicola & MAFF 301616 & $"$ \\
\hline pv. japonica & MAFF 301163 & $"$ \\
\hline pv. atropurpurea & MAFF 301307 & $"$ \\
\hline pv. morsprunorum & MAFF 301444 & $"$ \\
\hline pv. striafaciens & $P-71$ & NIAS \\
\hline pv. myricae & MAFF 301464 & NIAR \\
\hline pv. tomato & MAFF 301593 & $"$ \\
\hline P. viridiflava & MAFF 301130 & $"$ \\
\hline P. marginulis & 2153 & NIAS \\
\hline P. fluarescens & ATCC $13525^{\top}$ & ATCC \\
\hline$P$. aemeginosa & $\mathrm{P}-45$ & NIAS \\
\hline
\end{tabular}

ATCC: American Type Culture Collection.

NIAR: National Institute of Agrobiological Resources, Tsukuba, Japan.

KTES: Kagoshima Tobacco Experiment Station, Japan.

AKU: Faculty of Agriculture, Kyushu University, Fukuoka, Japan.

NIAS: National Institute of Agricultural Sciences, Tokyo, Japan.

Type culture: Small T at the shoulder of isolate number indicates type culture. 


\section{Direct colony TLC}

Each strain was cultured on a slant of King's B medium (Eiken Chem. Co.) at $30^{\circ} \mathrm{C}$ for 3 days. One loopful of bacterial colony was pasted directly on a TLC plate (Merck Co.) and dried completely. The plate was then developed with chloroform-methanol $(2: 1, \mathrm{v} / \mathrm{v})$ for $10 \mathrm{~min}$ and dried. Bacterial cells were scraped oul and again developed to the same direction with chloroform-methanol-water $(60: 25: 4, \mathrm{v} / \mathrm{v} / \mathrm{v})$. The amino lipids were detected by spraying with ninhydrin followed by heating at $100^{\circ} \mathrm{C}$ for $10 \mathrm{~min}$. The chromatograms were documented by photocopy (Matsuyama et al., 1993a,b,c; Matsuyama and Furuya, 1993d; Matsuyama, 1995a,b).

\section{GLC analysis}

Extraction of whole cellular fatty acids was conducted by the method of Gudmestad et al. (1988) with slight modification. Bacteria were grown in 523 broth (Kado and Heskett, 1970 ) at $30^{\circ} \mathrm{C}$ for $48 \mathrm{hr}$ by shaking. Five mg of lyophilized cells was methylated with $0.5 \mathrm{ml} 5 \% \mathrm{HCl}-$ methanol at $100^{\circ} \mathrm{C}$ for $3 \mathrm{hr}$ in a sealed glass tube to obtain fatty acid methyl ester (FAME) derivatives. The content was cooled at room temperature and transferred to a new eppendorf tube. Then, FAMEs were added with $0.5 \mathrm{ml}$ of distilled water and petroleum ether and centrifuged at $5000 \mathrm{rpm}$ for $5 \mathrm{~min}$. The solvent phase was collected in a new eppendorf tube, washed with $0.5 \mathrm{ml}$ distilled water to remove $\mathrm{HCl}$ and dehydrated by mixing with $0.5 \mathrm{~g}$ anhydrous sodium sulfate. The organic phase was concentrated by blowing nitrogen gas. FAMEs were analyzed by GLC chromatograph (Shimadzu C-R-7A Plus) equipped with HR-SS-10 capillary column. The column and injection-port temperature were maintained at $180^{\circ} \mathrm{C}$ and $250^{\circ} \mathrm{C}$, respectively, and the flow rate of nitrogen gas was $50 \mathrm{ml} / \mathrm{min}$. Average values of fatty acid composition were used to differentiate the strains. Relative similarities among the strains based on fatty acid composition were assessed with average linkage cluster analysis procedure using the statistics package software SYSTAT.

\section{Physiological and biochemical tests}

To test physiological and biochemical properties of the pear and radish strains the authentic methods reported by various researchers were applied as follows: Gram stain and levan formation (Schaad, 1988), production of fluorescent pigment on King's B medium (King et $a l ., 1954$ ), oxidase tests (Kovacs, 1956), potato soft rot (Lelliot el al,, 1966), arginine dehydrolase (Thornley, 1960), tobacco hypersensitive reaction (Klement. and Goodman, 1967). Carbon source utilizaiion tesis were also conducied by adding each carbon source $(0.1 \% \mathrm{wt} / \mathrm{vol})$ to the mineral base medium of Ayers et al. (1919). Carbon stock solutions were sterilized by autoclaving, except for the solutions sensitive to heat, which were sterilized by filtration. A suspension of bacterial cells grown on 523 slant was streaked onto each test medium, incubated at $30^{\circ} \mathrm{C}$ and evaluated periodically for 21 days. The results on the minimal medium without any addition of carbon source were used as controls.

\section{RESULTS AND DISCUSSION}

The pear and radish strains showed identical TLC chromatograms with those of the 


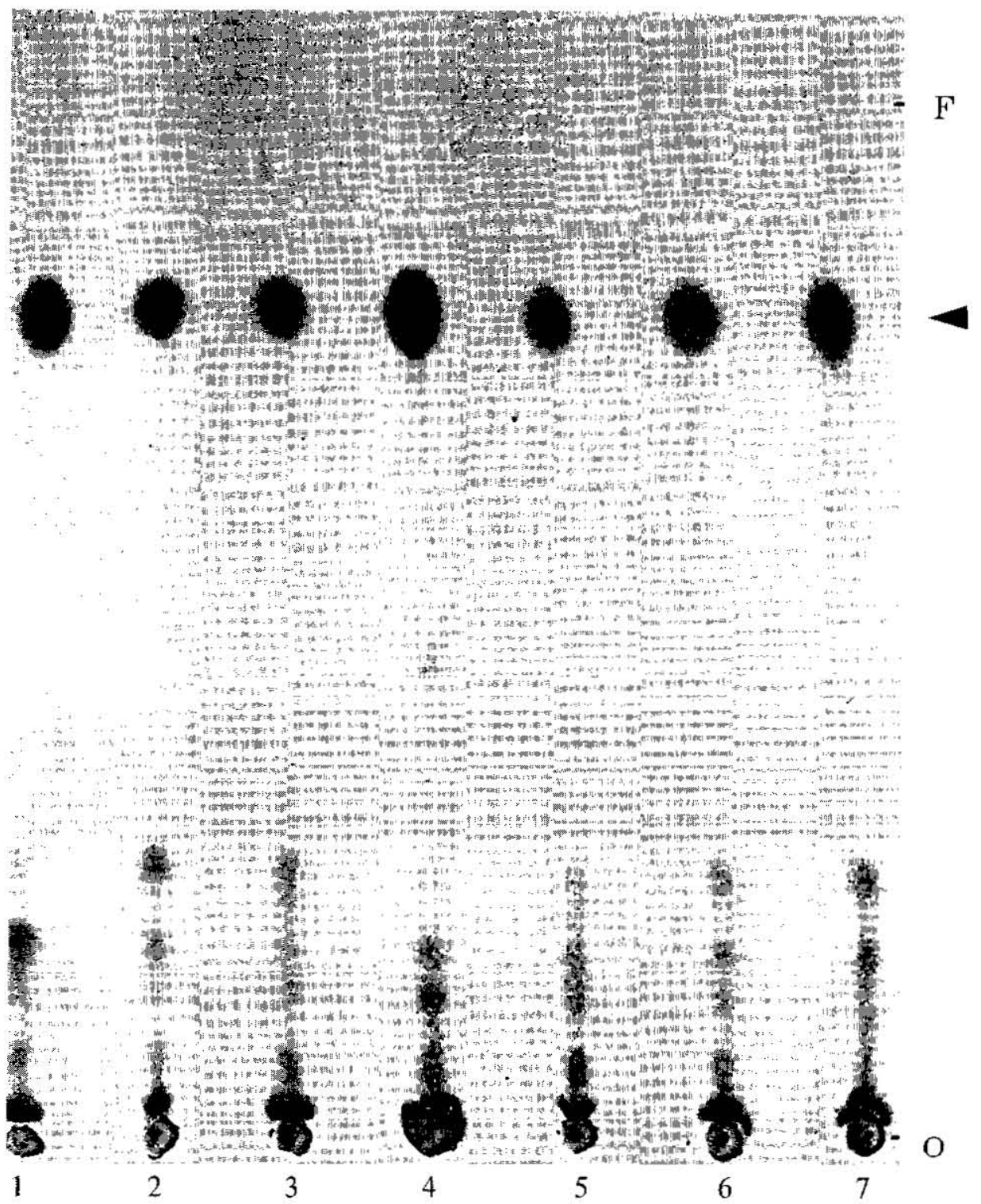

Fig. 1. TLC chromatograms of lipids from pear and radish strains and other reference strains by the direct colony $\mathrm{TLC}^{n}$.

1. P. marginaiz 2153

2. Radish strain

3. P. viridiflava MAFF 301130

4. $P$. syr. pv. syringae ATCC $19310^{\mathrm{T}}$

5. Pear strain

6. P. syr. pv. Lomalo MAFF 301593

7. P. syr. pv. tabaci Ku-7102

O: Origin, F: Solvent front

Arrow head indicates the common spot

i) The direct colony TLC method is described under materials and methods. 
Table 2. Percentage composition of whole cellular fatty acids in pear and radish strains and fluorescent pseudomonads used as reference.

\begin{tabular}{|c|c|c|c|c|c|c|c|c|c|c|}
\hline \multirow{2}{*}{ Bacterial species } & \multicolumn{10}{|c|}{ Fatty acid composition } \\
\hline & Lauric & $\begin{array}{c}3-\mathrm{OH} \\
\text { Capric } \\
\end{array}$ & Palmitic & $\mathrm{Un}^{23}-1$ & Palmitoleic & $\begin{array}{l}3-\mathrm{OH} \\
\text { Lauric } \\
\end{array}$ & Oleic: & Un-2 & Un-3 & $\begin{array}{c}2-\mathrm{OH} \\
\text { Palmitic }\end{array}$ \\
\hline Pear strain & 17.11 & 12.56 & 13.71 & 13.37 & 18.34 & 13.19 & 3.69 & 0.00 & 4.64 & 3.36 \\
\hline Radish strain & 18.58 & 8.44 & 12.52 & 9.72 & 25.83 & 9.63 & 9.05 & 0.00 & 0.00 & 6.20 \\
\hline P. syr. pv. syringae ATCC $19310^{\mathrm{T}}$ & 22.88 & 10.14 & 12.71 & 9.56 & 20.89 & 9.32 & 6.46 & 0.39 & 0.26 & 7.34 \\
\hline P. syr. pv. oryzae MAFF 301538 & 27.22 & 14.90 & 10.12 & 10.71 & 13.30 & 9.56 & 2.94 & 0.35 & 0.44 & 10.44 \\
\hline P. syr. pv. mori $\mathrm{P}-23$ & 21.05 & 13.17 & 10.04 & 11.83 & 17.11 & 11.54 & 4.68 & 0.45 & 0.81 & 9.28 \\
\hline P. syr. pv. labaci PA-28 & 25.53 & 15.72 & 8.12 & 10.47 & 12.58 & 11.39 & 3.22 & 0.17 & 0.51 & 11.25 \\
\hline P. syr, pv, tabaci $\mathrm{Ku}-7102$ & 26.27 & 14.11 & 8.73 & 11.54 & 10.56 & 10.16 & 3.68 & 0.83 & 1.04 & 12.64 \\
\hline P. syr. pv. theae MAFF 750001 & 19.41 & 13.81 & 8.67 & 12.45 & 19.18 & 11.78 & 3.42 & 0.46 & 0.13 & 10.66 \\
\hline P. syr. pv. lachrymans NIAS 1321 & 24.25 & 10.97 & 10.03 & 11.05 & 18.76 & 10.17 & 3.65 & 0.26 & 0.88 & 9.95 \\
\hline P. syr. pv. lachrymans NIAS 1319 & 27.28 & 11.84 & 10.01 & 11.32 & 15.30 & 9.89 & 3.21 & 0.37 & 0.38 & 10.65 \\
\hline P. syr. pv. pisi MAFF 301211 & 20.77 & 9.44 & 13.64 & 9.01 & 25.39 & 7.40 & 6.29 & 0.42 & 0.14 & 7.47 \\
\hline P. syr. pv. pisi MAFF 301213 & 16.91 & 13.16 & 12.97 & 13.37 & 22.53 & 11.83 & 4.93 & 0.00 & 0.51 & 3.77 \\
\hline P. syr. pv. phaseolicola MAFF 301616 & 18.43 & 13.12 & 11.13 & 11.36 & 20.21 & 10.79 & 5.32 & 0.00 & 0.00 & 9.62 \\
\hline P. syr. pv. japonica MAFF 301163 & 18.07 & 12.09 & 11.82 & 11.73 & 20.85 & 12.38 & 4.69 & 0.12 & 0.92 & 7.30 \\
\hline P. syr. pv. atropurpurea MAFF 301307 & 22.56 & 11.99 & 9.21 & 13.73 & 17.33 & 12.11 & 3.18 & 0.34 & 0.64 & 8.88 \\
\hline P. syr. pv. coronafaciens MAFF 301314 & 21.70 & 11.61 & 10.35 & 11.57 & 18.57 & 9.77 & 3.12 & 0.30 & 0.00 & 12.98 \\
\hline P. syr. pv. morsprunorum MAFF 30144 & 22.32 & 13.75 & 13.79 & 12.53 & 14.89 & 10.12 & 3.57 & 0.26 & 1.75 & 7.00 \\
\hline P. syr. pv. myricae MAFF 301464 & 16.74 & 12.78 & 13.79 & 15.34 & 14.86 & 13.99 & 5.16 & 0.00 & 3.18 & 4.13 \\
\hline P. syr. pv. tomato MAFF 301593 & 18.39 & 14.24 & 12.33 & 13.25 & 16.87 & 13.33 & 3.40 & 0.00 & 3.67 & 4.51 \\
\hline P. syr. pv. striafaciens P-71 & 18.37 & 12.83 & 14.46 & 12.40 & 18.20 & 11.61 & 5.62 & 0.00 & 1.80 & 4.70 \\
\hline P. viridiflava MAFF 301130 & 18.81 & 9.24 & 11.66 & 10.18 & 25.32 & 10.65 & 7.79 & 0.00 & 0.00 & 6.34 \\
\hline P. marginalis 2153 & 8.26 & 12.26 & 14.27 & 27.43 & 15.12 & 11.63 & 4.44 & 0.22 & 3.76 & 2.57 \\
\hline$P$ fluorescens ATCC $13525^{\mathrm{T}}$ & 9.45 & 15.35 & 15.09 & 26.12 & 11.50 & 12.27 & 4.84 & 0.00 & 2.14 & 3.20 \\
\hline P. aeruginosa $\mathrm{P}-45$ & 12.18 & 15.40 & 11.48 & 19.21 & 9.71 & 13.47 & 15.35 & 0.16 & 0.58 & 2.43 \\
\hline
\end{tabular}

a) Un-, Unidentified 
reference strains of fluorescent pseudomonads used in this study (Fig. 1). Only a single common spot (arrow-head in figure) which appears on the chromatograms of gramnegative bacteria except for Agrobacterium spp. was detected. A similar type TLC chromatogram was reported earlier for $P$. syringae (Matsuyama and Furuya, 1993d) and the chromatographic profiles suggested that the pear and radish strains belong to $P$. syringae or related speries.

In GLC analysis, ten fatty acids were detected and quantified as to bacterial strains used in this study. Among them, lauric acid, 3-OH capric acid, palmitic acid, palmitoleic acid, 3-OH lauric acid, oleic acid, 2-OH palmitic acid and one unidentified fatty acid (unidentified-1) were common in all strains including the pear and radish strains. $P$. marginalis, $P$. fluorescens and $P$. aeruginosa predominantly contained an unidentified fatty acid (unidentified-1) when compared with the compositions of $P$. syringae pathovars, $P$. viridiflava and pear and radish strains. Whereas lauric acid and palmitoleic acid were predominant in $P$. syringae pathovars, $P$. viridiflava, and pear and radish strains. The fatty acid composition also revealed that $P$. aeruginosa was different from $P$. marginalis and $P$. fluorescens for higher oleic acid content (Table 2). These results show that $P$. syringae pathovars and $P$. viridiflava can be clearly differentiated from $P$. marginalis, $P$. fluorescens and $P$. aeruginosa by their fatty acid compositions.

Euclidean distance

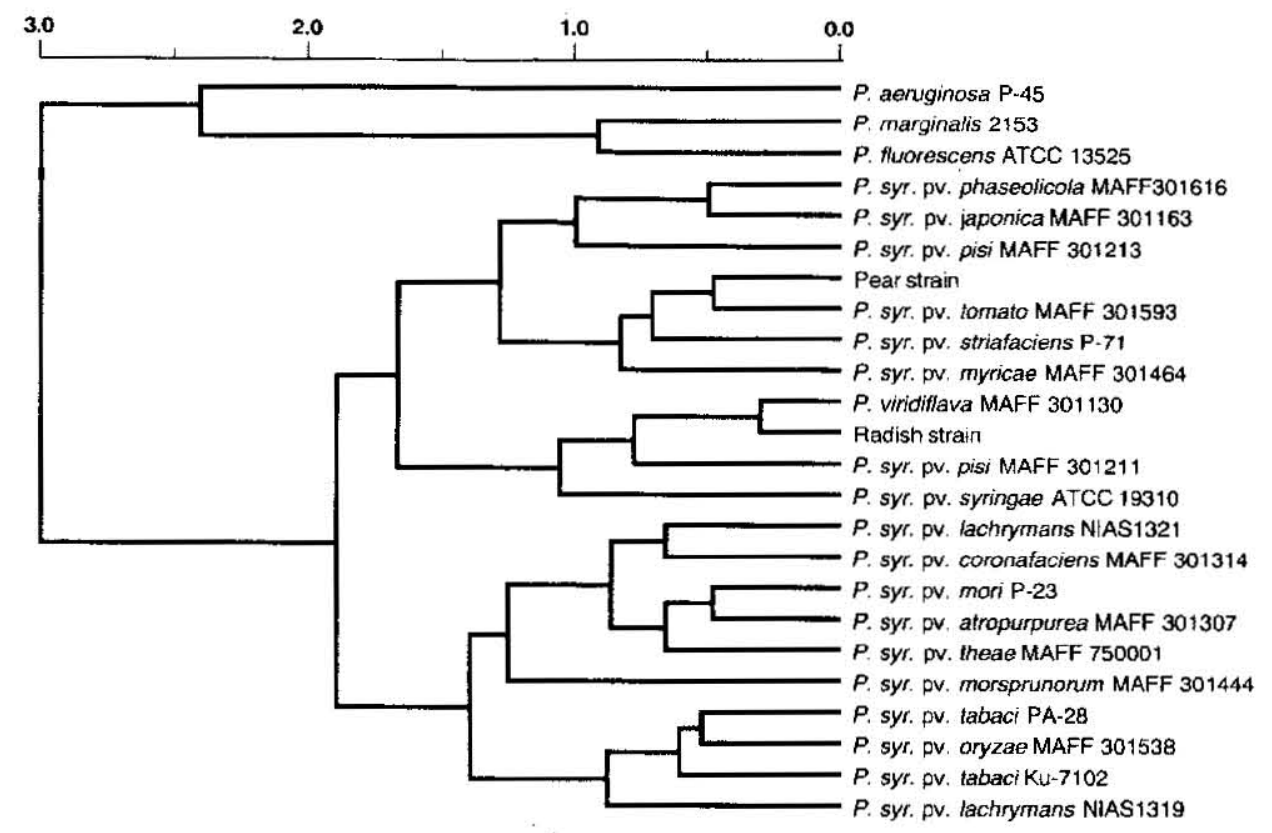

Fig. 2. Dendrogram of cluster analysis on pear and radish strains and other fluorescent pseudomonads used as refefence. 
Table 3. Physiological and biochemical tests for pear and radish strains and fluorescent pseudomonads

\begin{tabular}{|c|c|c|c|c|c|c|c|c|c|c|c|c|c|c|c|c|c|c|c|c|c|c|c|c|}
\hline \multirow[t]{2}{*}{ Tests } & \multicolumn{18}{|c|}{ Strain ${ }^{*}$} & \multirow[b]{2}{*}{19} & \multirow[b]{2}{*}{20} & \multirow[b]{2}{*}{21} & \multirow[b]{2}{*}{22} & \multirow[b]{2}{*}{23} & \multirow[b]{2}{*}{24} \\
\hline & 1 & 2 & 3 & 4 & 5 & 6 & 7 & 8 & 9 & 10 & 11 & 12 & 13 & 14 & 15 & 16 & 17 & 18 & & & & & & \\
\hline Gram stain & - & - & $=$ & - & - & - & - & - & $=$ & - & - & $=$ & $=$ & - & - & - & - & - & - & - & - & $=$ & - & \\
\hline Fluorescent pigment & + & + & + & + & + & + & + & + & + & + & + & + & + & + & + & + & + & + & + & + & + & + & + & + \\
\hline Tobacco HR & + & + & + & Chl. & + & + & + & + & chl. & chl. & chl. & + & + & + & + & Chl. & Chl. & Chl. & + & Chi. & Chl. & + & - & - \\
\hline Potato soft rot & - & + & - & - & - & - & - & - & - & - & - & - & - & - & - & - & - & - & - & - & - & + & - & - \\
\hline Oxidase & - & - & - & - & - & - & - & - & - & - & - & - & - & - & - & - & - & - & - & - & - & + & + & + \\
\hline Levan & ... & & + & . & + & + & + & + & + & + & + & + & + & + & + & + & + & - & + & + & + & + & + & + \\
\hline Arginine dihydolase & - & - & - & - & - & - & - & - & - & - & - & - & - & - & - & - & - & - & - & - & - & + & + & + \\
\hline Growth at $41^{\circ} \mathrm{C}$. & - & - & - & - & - & - & - & - & - & - & - & - & - & - & - & - & - & - & - & - & - & - & - & + \\
\hline Gelatin liquefaction & + & + & + & + & + & + & + & + & + & + & & + & + & + & + & + & - & + & + & + & - & + & + & + \\
\hline E'sculin hydrolysis & + & + & + & + & + & + & + & + & + & + & - & + & + & + & + & + & + & + & + & & - & - & - & - \\
\hline Tyrosinase activity & - & - & - & - & - & - & - & - & - & - & + & + & - & - & - & - & - & - & - & + & - & - & - & - \\
\hline $\begin{array}{l}\text { Utilization of: } \\
\text { Adonitol }\end{array}$ & - & - & -- & - & - & - & - & - & - & & & & & - & - & .. & - & - & - & - & - & + & + & - \\
\hline Erythritol & + & + & + & + & + & + & + & + & & - & + & + & + & + & + & - & - & - & + & & - & + & + & - \\
\hline Inositol & + & + & + & + & + & + & + & + & + & + & + & + & + & + & + & + & + & + & + & + & - & + & + & - \\
\hline Manuitol & + & + & + & + & + & + & + & + & + & + & + & + & + & + & + & + & + & + & + & + & - & + & + & + \\
\hline Sucrose & + & - & + & - & + & + & + & + & + & + & + & + & + & + & + & + & + & + & + & + & + & - & - & - \\
\hline Trehalose & - & - & - & - & - & - & - & - & - & - & - & - & - & - & - & - & - & - & - & - & - & + & + & - \\
\hline Sorbitol & + & + & + & + & + & + & + & + & + & + & + & + & + & + & + & - & + & + & + & + & - & + & + & - \\
\hline Cellobiose & - & & - & - & - & - & - & & & - & - & - & - & & & $\cdots$ & - & - & - & - & - & - & - & - \\
\hline D-Xylose & - & + & + & + & + & + & + & + & + & + & - & + & + & + & + & + & + & + & + & + & - & + & + & - \\
\hline Betaine & + & + & + & + & + & + & - & - & + & + & + & + & + & + & + & + & - & + & + & + & - & + & + & + \\
\hline L-Histidine & + & + & - & + & - & - & - & - & + & + & + & - & - & + & + & - & + & + & + & + & - & + & + & + \\
\hline DL-Homoserine & - & & . & -. & + & + & - & & & - & - & - & - & & & - & - & - & - & - & - & - & - & - \\
\hline Beta-alarine & - & - & - & - & - & - & - & - & - & - & - & - & - & - & - & - & - & - & - & - & - & + & + & + \\
\hline Anthranilate & - & - & - & - & - & - & - & - & - & - & + & - & - & - & + & - & - & - & - & - & - & + & + & + \\
\hline L-Ascorbate & - & - & - & - & - & - & - & - & - & - & - & - & - & - & - & - & - & - & - & - & - & - & - & - \\
\hline L-Tartrate & - & & - & & -- & - & + & + & + & + & + & - & - & - & - & - & - & - & - & + & - & - & - & - \\
\hline D-Tartrate & + & + & - & + & - & - & - & - & - & - & - & - & - & - & - & - & - & + & - & - & - & & & \\
\hline 2-Ketoglutarate & + & + & + & + & + & + & + & + & + & + & + & + & + & + & + & + & + & + & + & + & - & + & + & + \\
\hline Propionate & + & t & - & - & - & - & - & - & + & + & + & + & + & - & + & - & + & + & + & - & + & + & + & + \\
\hline Quinate & + & + & - & + & + & + & t & + & + & + & + & + & + & + & + & + & - & + & + & + & + & + & + & + \\
\hline L-Lactate & + & + & + & + & + & + & - & - & - & - & - & - & - & - & + & - & & - & + & - & - & + & + & + \\
\hline Trigonelline-HCl & + & + & + & + & + & + & + & + & + & + & + & - & - & - & + & + & + & + & + & + & + & - & - & - \\
\hline
\end{tabular}

, Positive; , Negative; Chl., Chlorosis

a) 1-Pear strain; 2-Radish strain; 3- $P$. syr. pv. syringae ATCC19310"; 4-P. viridiflana MAFF 301 130; 5-P. syr. pv. pisi MAFF 301211; 6-P. syr. pv. pisi MAFF 301213; 7-P. syr. pv. lachrymans NIAS 1319; 8 P. syr. pv. lachrymans NLAS 1321; 9-P. syr. pv. tabaci PA-28; 10-P. syr. pv. tabaci Ku-7102; 11-P. syr. pv. morspminorum MAFF 301444; 12-P. syr. pv. coronafaciens MAFF 301314; $13-P$. syr. pv. oryzae MAFF 301538; 14 . . syr. pv. atropurpurea pv. striafaciens $\mathrm{P}-71 ; 20-P$. syr. pv. myricae MAFF $301464 ; 21-P$. syr. pv. phaseolicola MAFF $301616 ; 22-P$. maryinalis $2153 ; 23-P$. futorescens ATCC 13525 $; 24-P$. aeruginosa $\mathrm{P}-45$. 
The dendrogram analysis based on fatty acid composition formed two major clusters (Fig. 2). The first group consisted of $P$. marginalis, $P$. fluorescens and $P$. aeruginosa whereas the second group contained $P$. syringae pathovars, $P$. viridiflava, and pear and radish strains. The latter group was again divided into five sub-clusters. In these subclusters, pear strain grouped with $P$. syr. pv. tomato MAFF 301593, $P$. syr. pv. striafaciens $\mathrm{P}-71$ and $P$. syr. pv. myricae MAFF 301464 and radish strain clustered with P. viridiflava MAFF 301130, P. syr. pv. pisi MAAFF 301211 and P. syr. pv. syringae ATCC 19310 (Fig. 2). Previously, Stead (1992) described three well defined profile-types in fluorescent pseudomonads, represented by $P$. syringae, $P$. aeruginosa, and $P$. fluorescens, where all plant pathogenic species tended to have profiles very similar to the profile of $P$. syr. pv. syringae, though some differences were observed among some taxa. This is also supported by the results of the present study. Hence, it is evident from the results of fatty acid analysis that the pear and radish strains belong to $P$. syringae or $P$. viridiflava.

Bacteriological properties of the pear and radish strains wcre examined in order to confirm the results of TLC and GLC andilyses. As summarized in Table 3, they were gramnegative, positive to fluorescent pigment production on King's B medium and caused hypersensitive reaction on tobacco leaves. They were negative in the following tests: oxidase activity, arginine dihydrolase activity and growth at $41^{\circ} \mathrm{C}$. Further, the other characteristics of pear and radish strains verified that they belong to $P$. syringae and $P$. viridiflava, respectively.

Although the determination of the pathovar of $P$. syringae was not possible, rapid identification of phytopathogenic bacteria using direct colony TLC and fatty acid analysis in combination with some selected physiological and biochemical tests is more convenient and practical.

\section{REFERENCES}

Ayers, S. H. P. Rupp and W. T. Johuson 1919 A study of the alkali-forming bacteria in milk. U. S. Dept. Agrie. Bull., 782

De Boer, S. H. and H. Sasser 1986 Differentiation of Erwinia carotovora subsp. carotovora and $E$ carotovora subsp. atroseptica on the basis of cellular fatty acid composition. Can. J. Microbiol, 32 : $796-800$

Gudmestad, N. C., P. J. Henningson and W. M. Bugbee 1988 Cellular fatty acid composition of strains of Conynebacterium michiganense subsp. sepedonicum from potato and sugar beet. Can. $J$. Microbiol., 34: 716-722

Kado, C. I. and M. G. Heskett 1970 Selective media for isolation of Agrobacterium, Corynebacterium, Emwinia, Pseudomonas, and Xanthomonas. Phytopathology, 60: 969-976

King, E. O., M. K. Ward and D. E. Raney 1954 Two simple media for the demonstration of pyocyanin and fluorescein. J. Lab. Clin. Med., 44: 301-307

Klement, A., and R. Goodman 1967 The hypersensitive reaction to infection by bacterial plant pathogens. Ann. Rev. Phytopathol., 5: 17-44

Kori, Y., N. Furuya, K. Tsuno and N. Matsuyama 1992 Differentiation of Erwinia chrysanthemi and $E$. carotowora subsp. carotovora by the cellular fatty acid analysis. J. Fac. Agr., Kyushu Uniw., 37: $173-178$

Kovacs, N. 1956 Identification of Pseudomonas pyocyana by the oxidasc reaction. Nature, 178: 703

Leiliott, R. A., E. Billing and A. C. Hayward 1966 A determinative scheme for the fluorescent plant pathogenic pseudomonads. J. Appl. Bacteriol., 29: 470-489 
Matsuyama, N., I. H. Mian, A. M. Akanda and N. Furuya 1993a Application of the direct colony TLC method for identification of phytopathogenic bacteria. J. Fac. Agr, Kyushu Univ., 37 (3, 4): 281-285

Matsuyama, N., I. H. Mian, A. M. Akanda and N. Furuya $1993 \mathrm{~b}$ Rapid identification of phytopathogenic bacteria by the dircet colony thin-layer chromatography (1). Proc. Assoc., Pl. Prot. Kyushu, 39: $60-64$

Matsuyama, N., I. H. Mian, A. M. Akanda and N. Furuya 1993c Comparative studies on thin-layer chromatograms of lipids from various phytopathogenic bacteria. Ann. Phytopath. Soc. Japan, 59: $528-534$

Matsuyama, N and N. Furuya 1993d Application of the direct colony TLC for identification of phytopathogenic bacteria (II) Chromatographic profile of Erwinia and Pseudomonas spp. J. Fac. Agr., Kyushu Lniw, $\mathbf{3 8}(1,2)$ : 89-95

Matsuyama, N. 1995a Trial for rapid identification of phytopathogenic bacteria by HPLC and the direct colony TLC. J. Fac. Agr., Kyushu univ, $\mathbf{4 0}(1,2)$ : 87-91

Matsuyama, N. 1995b Application of the direct colony TLC for identification of phytopathogenic bacteria (III). Distinction of the pseudomonads in the rRNA-homology group II (Burkholderia spp.) J. Fac. Agr., Kyushu lniv., 40(1, 2): 189-196

Matsuyama, T., M. Sogawa. K. Kaneda and I. Yano 1986 Rapid detection and identification of bacterial lipids by direct colony thin-layer chromatography. Proc. of 23rd Int. Symp. of Adv. in Chrom., Chiba, Japan, pp 127-128

Roy, M. A. 1988 Use of fatty acids for the identification of phytopalhogenic bacteria. Plant Disease, 72 460 .

Schaad, N. W. 1988 Laboratory guide for identification of plant pathogenic bacteria. 2nd Edition. The Bacteriology Committee of the American Phytopathologyical Society, pp 164

Stead, D. E. 1992 Grouping of plant-pathogenic and some other Pseudomonas spp. by using cellular fatty acid profiles. Int. J. Syst. Bacteriol., 42: 281-295

Thornley, M. J. 1960 The differentiation of Pseudomonas from other gram negative bacteria on the basis of arginine metabolism. J. Appl. Bacteriol., 1: 37-52

Wallace, P. L., D. G. Hollis, R. E. Weaver and C. W. Moss 1988 Cellular fatty acid composition of Kingella species, Cardiobacterium horninis, and Eikennella corodens. J Clin. Microbiol., 26: 1592-1594 